\title{
Learning Methods of Business Plan subject to Increase Entrepreneurial Skill, Entrepreneurial Intention and Entrepreneurial Spirit of Students
}

\author{
Maya Malinda
}

\begin{abstract}
This paper has purpose to reveal Learning method of Business Plan subject to increase entrepreneurial skill, intention and spirit of Maranatha Christian University students. The result showed $71.4 \%$ want to learn more about entrepreneurship, $52 \%$ want to be entrepreneur $42.9 \%$ want to be intrapreneur. From 63 students of Business plan class showed that $73 \%$ said presentation and discussion help them to increase their entrepreneurship skill. Meanwhile to increase their entrepreneurial intentions, learning methods entrepreneurial project and presentation of the project have the highest percentage. Be and investor, presentation and doing project are learning methods which have the highest degree for increase spirit of entrepreneurship.
\end{abstract}

Index Terms-Business plan, learning methods, entrepreneurial skill, entrepreneurial intention and entrepreneurial spirit.

\section{INTRODUCTION}

Entrepreneurship is a trend topic to discuss. Many people want to be entrepreneur, otherwise want to be intrapreneur. Entrepreneurs also made by entrepreneurship education. Many research shows that the educations of entrepreneur have a significant result to increase motivation, skill and spirit of entrepreneurship [1]. This research wants to find the effective learning method to teach and to equip students, so they can be motivated, skillful, and have a spirit of entrepreneur. The research will be taken from the student point of views in case study from several class business plan subject in sample University in Indonesia. In the last two decades, entrepreneurship education is one of the important program to create more educated entrepreneurs [2] including in Indonesia. Education will help people to learn anything. One of responsible for higher education is to equip citizen and society with the spirit of entrepreneurship. There has comparative study of entrepreneurship education in Taiwan and Singapore done by Min-Chun, Mark, Hao-Yun, \& Wen-Hsiung, their research revealed from the country-based standpoint, the findings include considering broader factors (i.e. history, education) in such a comparison of the similarities and differences among four universities, reflecting the reality in the Asian region and introducing the method application of comparative education research for the first time in entrepreneurship education. From holistic and specific perspectives of university-based entrepreneurship

Manuscript received May 12, 2019; revised August 1, 2019.

Maya Malinda is with Maranatha Christian University, Indonesia (e-mail: maya.malinda@eco.maranatha.edu). ecosystems (U-BEE), the findings consist of presenting similarities and differences based on the comparisons of each item and showing the classified findings. [3] Previous research revealed from the student's point of view, lecture, entrepreneur project and sales session believed can increase skill of entrepreneurship. [4] From those backgrounds, the purposes of this research are to reveal what learning method of entrepreneurship education can effective to increase, motivate an Indonesian student are being entrepreneurial, increasing the skill of entrepreneurship, spirit of entrepreneur and entrepreneurial intentions. The business plan is considered by many to be the most fundamental of entrepreneurial skills [5]. Therefore, this research using business plan subject to assess entrepreneurial skill. Entrepreneurial education very important to increase entrepreneurial spirit. [6] The goal of this research is to reveal passion of students about entrepreneur, to increase spirit of entrepreneurship, intention of entrepreneur and skill of entrepreneurship with learning method in Business Plan Subject.

\section{LEARning Method of Business Plan SubJeCt}

People learn anything with all they have and ways. Several learning methods are suitable for someone, but some methods are not necessarily. Collected several reasons of learning method implemented for business plan subject. First reason is Outcome Based Education (OBE). Definition of Outcome Based Education (OBE) is an educational theory that bases each part of an educational system around goals (outcomes). By the end of the educational experience, each student should have achieved the goal. There is no single specified style of teaching or assessment in OBE; instead, classes, opportunities, and assessments should all help students achieve the specified outcomes [7]. In this case, OBE need the role of the faculty adapts into instructor, trainer, facilitator, and/or mentor based on the outcome's goals. OBE Align with Learning Outcomes of Business plan subject at Maranatha Christian University for students are:

1) Students are able to apply problem solving and decision making with concepts of entrepreneurship and innovation (Application of knowledge).

2) Students are able to remember and understand the knowledge of entrepreneurship and innovation.

3) Students are able to think analytically by analyzing solving and decision making by means of analyzing concepts of entrepreneurship and innovation (Analytical thinking). 
4) Students are able to produce innovative products that come from self and group thinking and analysis and prove through short practice making innovative products and marketing them (Reflective thinking).

5) Students are able to describe and make decisions by considering the impact of decisions for interested parties in designing innovative products (Ethical understanding and reasoning).

6) Students are able to apply information technology in collecting and analyzing data, as well as making innovative products and providing interesting information (Information technology).

7) Students are able to communicate verbally and in writing in presenting sales reports and interesting and attractive innovative product papers (Written and oral communication).

8) Students understand the difficulties, challenges, hopes and personal experiences of business practices and implementation to develop enthusiasm, positive ambitions, and motivation for entrepreneurship which includes the ability to find and fill opportunities, take risks, recognize future needs, be dynamic and innovate to produce productivity higher both in carrying out their work in the organization and in conducting business. (Entrepreneurial spirit)

9) Students are able to collaborate in teams, learn to lead and be led, respect opinions and differences. (Interpersonal Relationship and Leadership)

There is no single learning method and teaching method appears to be adequate to achieve the objectives of the entrepreneurship course. [8] Therefore, have second reasons for of learning method implemented for business plan subject is learning pyramid. "The Learning Pyramid originates from the National Training Laboratories (NTL) for Applied Behavioral Science, 300 N. Lee Street, Suite 300, Alexander, VA 22314, USA. The percentages represent the average "retention rate" of information following teaching or activities by the method indicated. In fact, this diagram was originally developed and used by NTL in the early 1960s at NTL's Bethel, Maine, campus, but the organization no longer has or can find the original research that supports the numbers given. In 1954 a similar pyramid with slightly different numbers had appeared in a book, Audio-Visual Methods in Teaching, published by the Edgar Dale Dryden Press, New York. Bligh (1998) gives some evidence for the effectiveness of different teaching methods." [9]

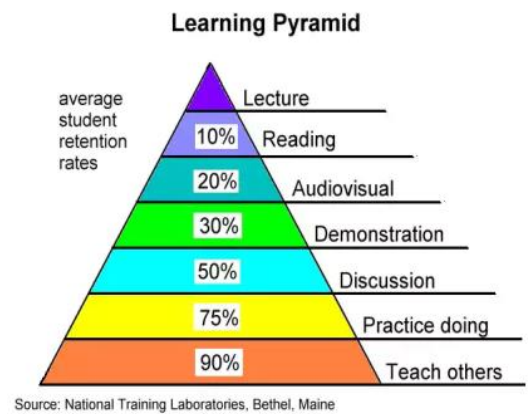

Graph 1. Learning pyramid national training laboratories.

Graph 1 showed that teach others is the highest percentage of average student retention rates. Mean that understanding and acceptability of student high when they have more interactive with others. Therefore, to implement learning methods must know students need and align with the purpose of learning. This research goal is to reveal effectivity for Business Plan subject to increase entrepreneurial skill, entrepreneurial intention and entrepreneurial spirit of students using eleven learning methods. The Learning method implement in one semester for this study case at Universitas Kristen Maranatha such as:

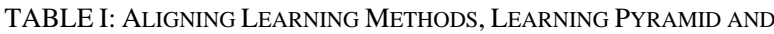
LEARNING OUTCOME

\begin{tabular}{|c|c|c|c|}
\hline \multicolumn{4}{|c|}{ LEARNING UUTCOME } \\
\hline No & Learning Method & $\begin{array}{l}\text { Learning } \\
\text { Pyramid }\end{array}$ & Learning Outcome \\
\hline 1. & Lecture (face to face) & $\begin{array}{l}\text { Lecture, } \\
\text { reading, } \\
\text { audiovisual }\end{array}$ & $\begin{array}{l}\text { Analytical thinking. } \\
\text { Entrepreneurial spirit. } \\
\text { Interpersonal } \\
\text { relationship and } \\
\text { leadership }\end{array}$ \\
\hline 2. & Entrepreneur project & $\begin{array}{l}\text { Demonstration, } \\
\text { discussion, } \\
\text { practice doing, } \\
\text { teaching each } \\
\text { other }\end{array}$ & $\begin{array}{l}\text { Application of } \\
\text { knowledge. } \\
\text { Entrepreneurial spirit. } \\
\text { Interpersonal } \\
\text { relationship and } \\
\text { leadership }\end{array}$ \\
\hline 3. & $\begin{array}{l}\text { Write } \\
\text { entrepreneurship } \\
\text { paper }\end{array}$ & $\begin{array}{l}\text { Reading, } \\
\text { practice doing. }\end{array}$ & $\begin{array}{l}\text { Analytical thinking. } \\
\text { Entrepreneurial spirit. }\end{array}$ \\
\hline 4. & Selling session & $\begin{array}{l}\text { Practice doing, } \\
\text { discussion }\end{array}$ & $\begin{array}{l}\text { Reflective thinking. } \\
\text { Interpersonal } \\
\text { relationship and } \\
\text { leadership }\end{array}$ \\
\hline 5. & Made a prototype & $\begin{array}{l}\text { Demonstration, } \\
\text { practice doing. } \\
\text { Teach others }\end{array}$ & $\begin{array}{l}\text { Analytical thinking. } \\
\text { Reflective thinking. }\end{array}$ \\
\hline 6. & $\begin{array}{l}\text { Presentation of the } \\
\text { project }\end{array}$ & $\begin{array}{l}\text { Demonstration, } \\
\text { practice doing, } \\
\text { discussion }\end{array}$ & $\begin{array}{l}\text { Reflective thinking. } \\
\text { Ethical understanding } \\
\text { and reasoning. } \\
\text { Information } \\
\text { technology. Written } \\
\text { and oral } \\
\text { communication. }\end{array}$ \\
\hline 7. & $\begin{array}{l}\text { Joint } \\
\text { entrepreneurship } \\
\text { seminar }\end{array}$ & $\begin{array}{l}\text { Lecture, } \\
\text { audiovisual, } \\
\text { reading }\end{array}$ & $\begin{array}{l}\text { Ethical understanding } \\
\text { and reasoning. } \\
\text { Entrepreneurial spirit. }\end{array}$ \\
\hline 8. & $\begin{array}{l}\text { Making video of the } \\
\text { product }\end{array}$ & $\begin{array}{l}\text { Practice doing, } \\
\text { audiovisual. }\end{array}$ & $\begin{array}{l}\text { Reflective thinking. } \\
\text { Information } \\
\text { technology. }\end{array}$ \\
\hline 9. & Discussion session & $\begin{array}{l}\text { Discussion, } \\
\text { practice doing. } \\
\text { Teach others }\end{array}$ & $\begin{array}{l}\text { Application of } \\
\text { knowledge. } \\
\text { Written and oral } \\
\text { communication. } \\
\text { Entrepreneurial spirit. } \\
\text { Interpersonal } \\
\text { relationship and } \\
\text { leadership }\end{array}$ \\
\hline 10. & Be an investor & $\begin{array}{l}\text { Demonstration, } \\
\text { discussion, } \\
\text { practice doing. } \\
\text { Teach others }\end{array}$ & $\begin{array}{l}\text { Application of } \\
\text { knowledge. Written } \\
\text { and oral } \\
\text { communication. } \\
\text { Entrepreneurial spirit } \\
\text { interpersonal } \\
\text { relationship and } \\
\text { leadership }\end{array}$ \\
\hline 11. & Survey to customer & $\begin{array}{l}\text { Discussion, } \\
\text { practice doing. }\end{array}$ & $\begin{array}{l}\text { Application of } \\
\text { knowledge. } \\
\text { Ethical understanding } \\
\text { and reasoning. } \\
\text { Interpersonal } \\
\text { relationship and } \\
\text { leadership }\end{array}$ \\
\hline
\end{tabular}

Source: researcher analysis

1) Lecture (face to face): Learning method in lecture 
means that Lecturer and students meeting in the class, discussion about theory and practice entrepreneurship and how to write business plan.

2) Entrepreneur project: The group of students doing the project, start from made a product design until ready to sell.

3) Write entrepreneurship paper: The students in group made Business plan

4) Selling session: The group of students should have experience to sell the product innovation.

5) Made a prototype: The students before sell the product must make prototype and test and survey to customer.

6) Presentation of the project: After doing entrepreneurship project, the students must present and explain their business plan.

7) Joint entrepreneurship seminar: The students have several opportunities to attend entrepreneurship seminar be a participant.

8) Making video of the product: The group of students made video to promote their product.

9) Discussion session: Discussion session is the part of Lecture and presentation

10) Be an Investor: The students try to be investor, they must invest their own money doing the project, for buy material, transport cost, marketing cost etc.

11) Survey to Customer: The students made interview with customer to get an idea and get suggestions.

Table I showed aligning learning methods, learning pyramid and learning outcome for Business Plan Subject at Maranatha Christian University, Bandung Indonesia. There are Eleven learning methods implemented in to learning process. Aligning with retention rates on Learning Pyramid have seven level, lecture, reading, audiovisual, demonstration, discussion, practice doing and teach others, the highest level when students can teach others and can help people. Aligning with Learning outcome of Business Plan subject at Maranatha Christian University, already explained before.

\section{DAta AND Methodology}

Population data is from the 63 students from two classes. $54 \%$ females and $46 \%$ males, their ages from 18 to 24 years old and they are mostly in fifth semester. The purposes of this paper revealed which effective learning method from a student's perspective can help them to enhance skill, intention and spirit of entrepreneurs from students' point of views. Methodology in this research using questionnaire to get information and feedback from students. Bergmann, Geissler, Allow [10], use perception of the student to distinguish effectivity of learning method. They research from students' perceptions of the entrepreneurial climate in Germany public university. Seventy-third student fill the questionnaire, and select and give ranking, which learning method can increase skill, motivation and spirit of entrepreneurship.

The Methodology of this research is a descriptive verification and analyzes study. Verification method was a study method aimed to test the effectiveness learning method used in Indonesia to teach student to have entrepreneurial skill, be motivated and entrepreneurial spirit. Observing class and learning method the university used to teach and to equip student have entrepreneurial skill, motivated and spirit of entrepreneurship. After completing the program, this study uses a questionnaire to obtain data from students in Indonesia, to know result from student's perception. Allow perception of the student already done by others researcher [10] .They research from students' perceptions of the entrepreneurial climate in Germany public university. The student will fill the questionnaire, and select and give ranking, which learning method can increase skill, motivation and spirit of entrepreneurship. Align with Olokundun et al. research that experiential pedagogical approach can be used to stimulate business opportunity identification potentials in entrepreneurship students [11], [12].

\section{RESULT}

Intention, as the starting point of pursuing self-employment and creating new ventures, is crucial before actually establishing a business enterprise. [13] entrepreneurial intentions are assumed to predict individual's choice to found their own firms [14] in Chart 1 showed the result that Female students have intention to be entrepreneur $48,28 \% .44,83 \%$ have passion to be intrapreneur and $72.41 \%$ have passion to learn more about entrepreneurship.

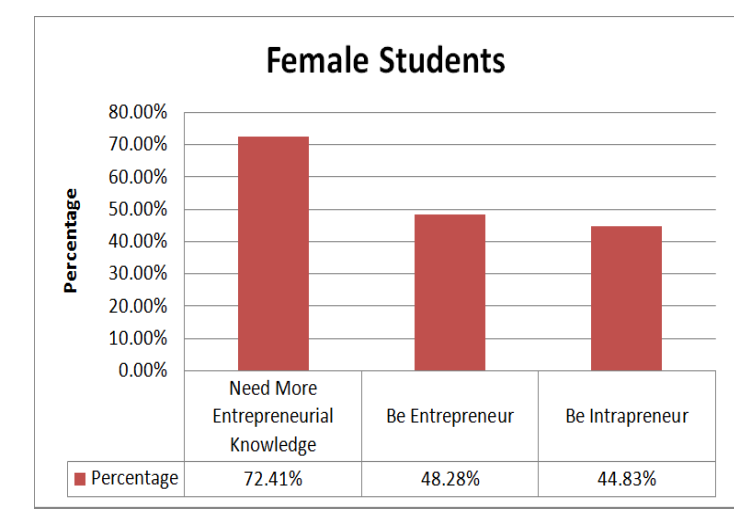

Sources: 29 female students population who took business plan subject Chart 1. Percentage of female students.

Chart 2 showed that Male students have more intention to be entrepreneurs compare with Female Students. Result showed that more than $50 \%$ male students want to be entrepreneurs.

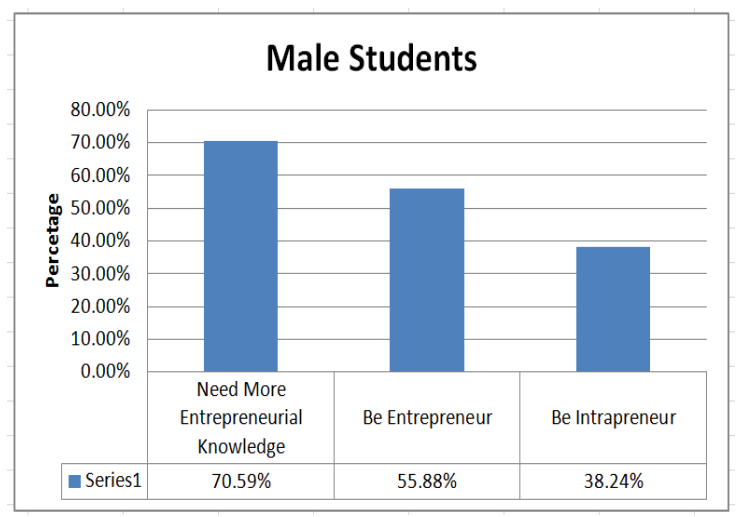

Sources: 34 male students population who took business plan subject Chart 2. Percentage of male students. 
When seen more detail comparison from Chart 1 and 2, female students need more entrepreneurial knowledge than male students. Percentage of female students who want to be intrapreneur higher than male students.

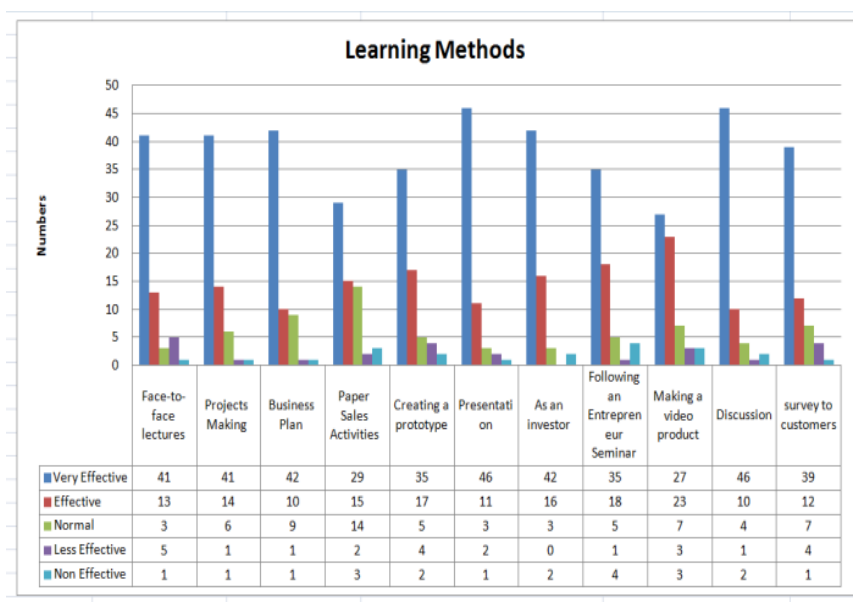

Sources: 63 students population who took business plan subject

Chart 3. Number of students answers effective learning methods.

Chart 3 Show the number of students to answer degree of effectiveness learning methods implemented during Business plan subject. The result show that the highest score for learning methods very effective for presentation and discussion, 46 students' answers followed by try becoming investor and make business plan paper. Doing project and face to face lecturer also get high score, more than $60 \%$ student answers very effective.

TABLE II: PERCENTAge Degree of LEARning Methods Group A (1-6) TO INCREASE ENTREPRENEURSHIP SKILL

\begin{tabular}{|c|c|c|c|c|c|c|}
\hline Degree & $\begin{array}{c}\text { Face-to- } \\
\text { face } \\
\text { lectures }\end{array}$ & $\begin{array}{c}\text { Projects } \\
\text { Making }\end{array}$ & $\begin{array}{c}\text { Business } \\
\text { Plan }\end{array}$ & $\begin{array}{c}\text { Paper } \\
\text { Sales } \\
\text { Activities }\end{array}$ & $\begin{array}{c}\text { Creating a } \\
\text { prototype }\end{array}$ & Presentation \\
\hline Very Effective & $65 \%$ & $65 \%$ & $67 \%$ & $46 \%$ & $56 \%$ & $73 \%$ \\
\hline Effective & $21 \%$ & $22 \%$ & $16 \%$ & $24 \%$ & $27 \%$ & $17 \%$ \\
\hline Normal & $5 \%$ & $10 \%$ & $14 \%$ & $22 \%$ & $8 \%$ & $5 \%$ \\
\hline Less Effective & $8 \%$ & $2 \%$ & $2 \%$ & $3 \%$ & $6 \%$ & $3 \%$ \\
\hline Non Effective & $2 \%$ & $2 \%$ & $2 \%$ & $5 \%$ & $3 \%$ & $2 \%$ \\
\hline
\end{tabular}

Sources: 63 students population who took business plan subject

Percentage Degree of Learning Methods showed at Table II and Table II. The result of Percentage Degree of Learning Methods on Table I and Table II show that Presentation and Discussion learning method $73 \%$ very effective to increase entrepreneurship skill. Making video and sales activities have percentage of effective less than $50 \%$.

TABLE III: PERCENTAGE DEgREE OF LEARning METHods Group B (7-11) TO INCREASE ENTREPRENEURSHIP SKILL

\begin{tabular}{|c|c|c|c|c|c|}
\hline Degree & $\begin{array}{c}\text { As an } \\
\text { investor }\end{array}$ & $\begin{array}{c}\text { Following an } \\
\text { Entrepreneur } \\
\text { Seminar }\end{array}$ & $\begin{array}{c}\text { Making a } \\
\text { video } \\
\text { product }\end{array}$ & Discussion & $\begin{array}{c}\text { Survey to } \\
\text { customers }\end{array}$ \\
\hline Very Effective & $67 \%$ & $56 \%$ & $43 \%$ & $73 \%$ & $62 \%$ \\
\hline Effective & $25 \%$ & $29 \%$ & $37 \%$ & $16 \%$ & $19 \%$ \\
\hline Normal & $5 \%$ & $8 \%$ & $11 \%$ & $6 \%$ & $11 \%$ \\
\hline Less Effective & $0 \%$ & $2 \%$ & $5 \%$ & $2 \%$ & $6 \%$ \\
\hline Non Effective & $3 \%$ & $6 \%$ & $5 \%$ & $3 \%$ & $2 \%$ \\
\hline
\end{tabular}

Sources: 63 students population who took business plan subject

Table IV and Table V show percentage Degree of Learning Methods that Presentation is very effective learning method to increase entrepreneurship intention. Table IV 75\% of students stated presentation is very effective method to increase entrepreneurship intention, followed by project making have $71 \%$ stated very effective. All learning methods have percentage more than $50 \%$ of students.

TABLE IV: PERCENTAGE DEgREE OF LEARNING METHOdS GROUP A (1-6) TO INCREASE ENTREPRENEURSHIP INTENTION

\begin{tabular}{|l|c|c|c|c|c|}
\hline \multicolumn{1}{|c|}{ Degree } & As an investor & $\begin{array}{c}\text { Following an } \\
\text { Entrepreneur } \\
\text { Seminar }\end{array}$ & $\begin{array}{c}\text { Making a } \\
\text { video } \\
\text { product }\end{array}$ & Discussion & $\begin{array}{c}\text { survey to } \\
\text { customers }\end{array}$ \\
\hline Very Effective & $59 \%$ & $56 \%$ & $52 \%$ & $67 \%$ & $62 \%$ \\
\hline Effective & $27 \%$ & $25 \%$ & $37 \%$ & $24 \%$ & $24 \%$ \\
\hline Normal & $11 \%$ & $5 \%$ & $10 \%$ & $3 \%$ & $11 \%$ \\
\hline Less Effective & $2 \%$ & $8 \%$ & $0 \%$ & $5 \%$ & $3 \%$ \\
\hline Non Effective & $2 \%$ & $6 \%$ & $2 \%$ & $2 \%$ & $0 \%$ \\
\hline
\end{tabular}

Sources: 63 students population who took business plan subject

TABLE V: Percentage Degree of LeARning Method Group B (7-11) TO INCREASE ENTREPRENEURSHIP INTENTION

\begin{tabular}{|l|c|c|c|c|c|c|}
\hline \multicolumn{1}{|c|}{ Degree } & $\begin{array}{c}\text { Face-to- } \\
\text { face } \\
\text { lectures }\end{array}$ & $\begin{array}{c}\text { Projects } \\
\text { Making }\end{array}$ & $\begin{array}{c}\text { Business } \\
\text { Plan }\end{array}$ & $\begin{array}{c}\text { Paper } \\
\text { Sales } \\
\text { Activities }\end{array}$ & $\begin{array}{c}\text { Creating } \\
\text { a } \\
\text { prototype }\end{array}$ & Presentation \\
\hline Very Effective & $68 \%$ & $71 \%$ & $65 \%$ & $57 \%$ & $52 \%$ & $75 \%$ \\
\hline Effective & $22 \%$ & $21 \%$ & $22 \%$ & $22 \%$ & $35 \%$ & $19 \%$ \\
\hline Normal & $3 \%$ & $5 \%$ & $11 \%$ & $16 \%$ & $6 \%$ & $3 \%$ \\
\hline Less Effective & $5 \%$ & $2 \%$ & $2 \%$ & $3 \%$ & $5 \%$ & $3 \%$ \\
\hline Non Effective & $2 \%$ & $2 \%$ & $0 \%$ & $2 \%$ & $2 \%$ & $0 \%$ \\
\hline
\end{tabular}

Sources: 63 students population who took business plan subject

TABLE VI: PERCENTAgE DEgREE OF LEARNING METHOD GROUP A (1-6) TO INCREASE ENTREPRENEURSHIP SPIRIT

\begin{tabular}{|l|c|c|c|c|c|c|}
\hline \multicolumn{1}{|c|}{ Degree } & $\begin{array}{c}\text { Face-to- } \\
\text { face } \\
\text { lectures }\end{array}$ & $\begin{array}{c}\text { Projects } \\
\text { Making }\end{array}$ & $\begin{array}{c}\text { Business } \\
\text { Plan }\end{array}$ & $\begin{array}{c}\text { Paper } \\
\text { Sales } \\
\text { Activities }\end{array}$ & $\begin{array}{c}\text { Creating a } \\
\text { prototype }\end{array}$ & Presentation \\
\hline Very Effective & $65 \%$ & $70 \%$ & $56 \%$ & $52 \%$ & $52 \%$ & $71 \%$ \\
\hline Effective & $21 \%$ & $19 \%$ & $24 \%$ & $29 \%$ & $29 \%$ & $19 \%$ \\
\hline Normal & $6 \%$ & $6 \%$ & $13 \%$ & $16 \%$ & $13 \%$ & $5 \%$ \\
\hline Less Effective & $2 \%$ & $2 \%$ & $6 \%$ & $2 \%$ & $5 \%$ & $3 \%$ \\
\hline Non Effective & $6 \%$ & $3 \%$ & $2 \%$ & $2 \%$ & $2 \%$ & $2 \%$ \\
\hline
\end{tabular}

Sources: 63 students population who took business plan subject

Table VI and Table VII showed percentage of the degree of learning methods to increase entrepreneurship spirit.

The result revealed that the highest percentage is doing presentation $71 \%$. Furthermore $70 \%$ students state project making and try being investor very effective to increase entrepreneurship spirit. In Table V and Table VI showed that for all learning method considered very effective more than $52 \%$.

TABLE VII: PERCENTAGE DEgREE OF LEARNING METHOD GROUP B (7-11) TO INCREASE ENTREPRENEURSHIP SPIRIT

\begin{tabular}{|l|c|c|c|c|c|}
\hline \multicolumn{1}{|c|}{ Degree } & As an Investor & $\begin{array}{c}\text { Following an } \\
\text { Entrepreneur } \\
\text { Seminar }\end{array}$ & $\begin{array}{c}\text { Making a } \\
\text { video product }\end{array}$ & Discussion & $\begin{array}{c}\text { Survey to } \\
\text { customers }\end{array}$ \\
\hline Very Effective & $70 \%$ & $63 \%$ & $57 \%$ & $68 \%$ & $67 \%$ \\
\hline Effective & $16 \%$ & $21 \%$ & $22 \%$ & $17 \%$ & $14 \%$ \\
\hline Normal & $11 \%$ & $6 \%$ & $11 \%$ & $8 \%$ & $16 \%$ \\
\hline Less Effective & $0 \%$ & $3 \%$ & $3 \%$ & $3 \%$ & $2 \%$ \\
\hline Non Effective & $3 \%$ & $6 \%$ & $6 \%$ & $3 \%$ & $2 \%$ \\
\hline
\end{tabular}

Sources: 63 students population who took business plan subject

\section{CONCLUSIONS}

Conclusions of this research first whole learning method implemented very effective to increase entrepreneurship skill, entrepreneurial intention and spirit of entrepreneurship. 
Second, learning method of presentation and discussion proved that increase entrepreneurship skill. Third, presentation their project considered has the highest percentage. Fourth, being an investor learning method increase entrepreneurial spirit have seventy percent. Fifth, for whole learning method students state that more than forty three percent very effective to increase entrepreneurship skill, more than fifty two percent to increase entrepreneurship intention and more than fifty two percent to increase entrepreneurship spirit. Conclusion entrepreneurial Education in Business plan subject considered to have impact to increase entrepreneurship skill, entrepreneurial intention and spirit of entrepreneurship [5], [6], [14].

\section{CONFLICT OF INTEREST}

The author declares no conflict of interest.

\section{AUTHOR CONTRIBUTION}

The author wrote the paper and agreed for final version.

\section{ACKNOWLEDGMENT}

Thank you for all students who have participated in this research. Thank you to Universitas Kristen Maranatha for support in this research. Researcher always open mind and need for suggestion and opinion to increase quality of this paper.

\section{REFERENCES}

[1] D. F. Kuratko, "The emergence of entrepreneurship education: Development, trends, and challenges," Entrepreneurship Theory and Practice, 2005, vol. 29, no. 5, pp. 577-597.

[2] A. Ghina, "Effectiveness of entrepreneurship education in higher education institutions," Procedia - Social and Behavioral Sciences, 2014, vol. 115, pp. 332-345.

[3] Y. Min-Chun et al., "A comparative study of entrepreneurship education between Singapore and Taiwan," Management Decision, 2017, vol. 55, no. 7, pp. 1426-1440.

[4] M. Malinda, "Effectiveness of entrepreneurship and innovation learning methods. Case Study at Universitas Kristen Maranatha, Bandung, Indonesia," International Journal of Business and Administrative Studies 2018, vol. 4, issue 3, 2018, pp. 122-128.

[5] L. Smith, W. K. Schallenkamp, and D. E. Eichholz, Entrepreneurial Skills Assessment: An Exploratory Study, vol. 4, 2007.

[6] E. Qosja and E. Druga, Entrepreneurial Spirit and Factors Affecting It: Case Study Based on the Students of the European University of Tirana, vol. 1, 2015, pp. 680-691.

[7] W. Spady, Outcome-Based Education: Critical Issues and Answers, Arlington Virginia: American Association of School Administrators, 1994.

[8] S. Z. Ahmad, A. R. A. Bakar, and N. Ahmad, "An evaluation of teaching methods of entrepreneurship in hospitality and tourism programs," The International Journal of Management Education, 2018, vol. 16 , no. 1 , pp. $14-25$.

[9] Problem-Based Learning: Exploiting Knowledge of how People Learn to Promote Effective Learning, AU - Wood, E J. Bioscience Education, 2004, vol. 3, no. 1, pp. 1-12.

[10] H. Bergmann et al., "The climate for entrepreneurship at higher education institutions," Research Policy, 2018, vol. 47, no. 4, pp. 700-716.

[11] M. A. Olokundun et al., "Experiential pedagogy and shared vision: A focus on identification of business opportunities by Nigerian university students," Journal of Entrepreneurship Education, 2017, vol. 20, no. 2, pp. 1-12.

[12] M. Olokundun et al., "The effect of non traditional teaching methods in entrepreneurship education on students entrepreneurial interest and business startups: A data article," Data in Brief, 2018, vol. 19, pp. 16-20.

[13] N. B. C. Nawi et al., "Entrepreneurial intention and startup preparation: A study among business students in Malaysia AU - Mamun, Abdullah Al," Journal of Education for Business, 2017, vol. 92, no. 6, pp. 296-314.

[14] I. Ajzen, "The theory of planned behavior," Organizational Behavior and Human Decision Processes, 1991, vol. 50, no. 2, pp. 179-211.

Copyright $\odot 2019$ by the authors. This is an open access article distributed under the Creative Commons Attribution License which permits unrestricted use, distribution, and reproduction in any medium, provided the original work is properly cited (CC BY 4.0).

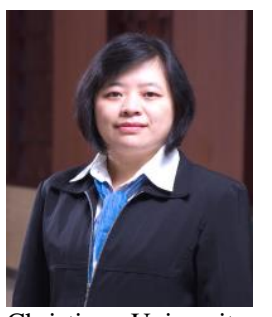

Maya Malinda was born in Bandung, Indonesia. She graduate from $\mathrm{PhD}$ in business program at Chung Yuan Christian University, Taiwan. She took her master's degree in Bandung Institute of Technology Indonesia; her field was the development studies graduate program, in special topic innovation and entrepreneurship. She got a bachelor's degree from Faculty of Economic Universitas Kristen Maranatha / Maranatha Christian University; Bandung, Indonesia with field of study was Management.

Her working experience:

-2008-2012 Secretary of Management Department, Faculty of Economics Maranatha Christian University.

-2007-2008: Teaching Learning Center, Maranatha Christian University.

-2003-2007: Coordinator program of the Maranatha Student Career Center.

-November 2001-Oktober 2006: Editor of Management Journal, Published by Faculty of Economics (ISSN 1411-9293).

-1999-Present: Lecturer at the Department of Management, Maranatha Christian University and teaches Personal financial planning, entrepreneurship, capital market at undergraduate level.

-2016-2018: Director of Cooperation and Alumni Affairs.

-2018-Now: Cheif Executive of Entrepreneurship Major at Management department

Ms Maya Malinda has Professional Certifications for Financial Planner (Certified Financial Planner, $\mathrm{CFP}{ }^{\circledR}$ because she has a passion to inspire and to equip people to plan their finances goal.

Her research areas/interests are international finance, entrepreneurship, financial management and personal financial planning. 